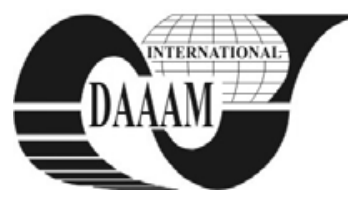

\title{
CONSIDERATIONS REGARDING THE RELATION BETWEEN FISCALITY AND TECHNOLOGICAL INNOVATION IN ROMANIA
}

\author{
DOMIL, A[ura] E[manuela]; ARTENE, A[lin] E[manuel] \& COSTESCU, I[rina] D[aniela]
}

\begin{abstract}
In this paper we intend to emphasize both theoretical and practical aspects regarding the identification of the existing limits in the actual context, regarding technological innovation and also to identify the constraints witch undergo the idea market.
\end{abstract}

Key words: fiscality, technological innovation, entrepreneurial creativity

\section{INTRODUCTION}

Technological innovation, a concept with expanded understanding, must be seen as an act of human creation to be considered an essential coordinated in the technical progress of an economic entity.

When we talk about innovation we are referring to change that can take different forms:

- product innovation - changes in the products or services which an economic entity offers;

- process innovation - changes in the ways in which they are created and delivered;

- position innovation - changes in the context in which the product or services are introduced;

- paradigm innovation ${ }^{1}$ - changes in the underling mental models which frame what the economic entity does.

\section{APPROACHES TO TECHNOLOGICAL INNOVATION IN TIME}

Developing and adapting an action plan in order to increase the quality of life in our country, in accordance with trends manifested on European and international level, aims creating a common framework for achieving actions. This problem concerns not only a country, is a global action, with its major purpose of developing the idea market.

Looking on technological innovation beyond the scientific discovery, as a process of creative destruction Joseph Alois Schumpeter introduces logical sequence ,invention - innovation - technology dissemination”, which becomes widely accepted among economists.

Hereby, „radical” innovations ${ }^{2}$ determines major changes in the world, while, "incremental" innovations continuously covers the changing process. Endogenous force generation in the business cycle is performed by the entrepreneur, him being the one who makes new combinations radically changing the existing structures.

Analyzing specialty literature we could identify the main problems affecting the development of innovation and are based on factors such as financial systems, distribution, marketing, intellectual property and not least improvement programs.

Wealth created by people in the production process, with the help of constituent elements of the capital in other words, the subject of economics is represented by the study of "nature

\footnotetext{
${ }^{1}$ J.Tidd, J.R. Bessant, K.Pavitt, Managing Innovation: integrating technological, market and organizational change, John Wiley \& Sons Publisher, 2001, ISBN 978-0471496151

${ }^{2}$ Schumpeter J.A., Poate supravieți capitalismul? Distrugerea creatoare și viitorul economiei globale, Ed. Publică, București, 2011, ISBN 978-973-1931-65-
}

and laws of production and distribution of wealth ", idea promoted by the Austrian economic school by John Stuart Mill. Economic science must not concern only on the level of wealth, but also to investigate the economic conditions of the nation and individuals, in terms of institutions and social relations, of human nature, and also the moral and psychological causes.

Production conditions are social and natural, materialized through conjugate action of the three factors of production: labor, nature and capital. Ludwig von Mises refers to three types of fiscal interventionism. The various methods of taxation can be employed to regulate the economy.

\section{TECHNOLOGICAL INNOVATION IN ROMANIA}

Innovation is a succession of activities which the management entity pursues in order to produce new products and services, intended for sale. Meanwhile, also in the category of innovation processes are included activities of expanding the markets, improving the functioning of supply, of production process, of maintenance equipment, of distribution channels, of service and, last but not least, improving administrative and management activities of the company.

Innovation, according to the OECD definition is the overall process of technological and commercial creativity, transfer of new ideas or a new concept to the final stage of a new product, process or service accepted by the market.

Types of innovation can be considered the following:

- product innovation is the introduction of a good or service that are new or significantly improved in terms of their characteristics or intended use. These include significant improvements in technical specifications, components and materials, the embedded software, the friendly attitude regarding users or other functional characteristics. Product innovations can use new knowledge or technology, or can be based on new uses or combinations of existing knowledge and technologies. Process innovation is the implementation of new or significantly improved methods of production (eg new manufacturing processes or technology flows) or a new delivery method. This includes significant changes in techniques, technological equipment and / or of software. The result of process innovation should be significant in terms of: production level, product quality or reducing production and distribution costs.

- organizational innovation is implementing a new way of organizing the company's business practices in organizing jobs or foreign relations of the company. Such an innovation aimed at enhancing business performance by reducing administrative costs or transaction, improving satisfaction at work (and thus labor productivity) or reduces supply costs. In the U.S. many organizational innovations have taken place in distribution.

- marketing method involving significant changes in product design or packaging, new methods of selling, product placement, product promotion or pricing on the policy. Marketing innovations are aimed to better meet customer needs, follows the opening of new markets or a new positioning of the company's products on the market, with the objective of increasing company sales. 
EU member countries performance was measured in the 8th edition of the European Innovation Scoreboard published report conducted by the Maastricht Economic and Social Research and Training Centre on Innovation and Technology. According to the report, the difference of performance in innovation divided the EU countries into four groups:

- Group 1. Switzerland, Sweden, Finland, Germany, Denmark and the UK are leaders in innovation, with performances well above the EU average.

- Group 2. Austria, Ireland, Luxembourg, Belgium, France and the Netherlands are on the next place, with performances above the EU average.

- Group 3. Cyprus, Iceland, Estonia, Slovenia, Czech Republic, Norway, Spain, Portugal, Greece and Italy are moderate innovators with performances in innovation below the EU average.

- Group 4. Malta, Hungary, Slovakia, Poland, Lithuania, Croatia, Romania, Latvia, Bulgaria and Turkey are countries in recovery with innovation performance well below the EU average.

Romania and Bulgaria are the countries with the fastest performance improvement with an increase of $5.5 \%$ over the past five years.

Romania $^{3}$ is one of the growth leaders among the Catching up countries, with an innovation performance well below the EU27 average but a rate of improvement that is one of the highest of all countries. Relative strengths, compared to

the country's average performance, are in Innovators and Economic effects and relative weaknesses are in Finance and

support and Throughputs. Over the past 5 years, Finance and support and Throughputs have been the main drivers of the improvement in innovation performance, in particular as a result from strong growth in Public R\&D expenditures (18.0\%), Private credit (25.8\%), Broadband access by firms (46.7\%), Community trademarks (34.5\%) and Community designs (37.3\%). Performance in Firm investments, Linkages \& entrepreneurship, Innovators and Economic effects has increased at a slower pace.

Romania's current situation is due to the fact that until today it has remained a haven of general culture.

In Romania it could not be held a special ideas marketplace and so the general ideas market, as long as it functioned, has developed into a system of general culture domination.

\section{POLICY AND FISCALITY OF TECHNOLOGICAL INNOVATION}

Innovation policy will pursue the integration of process in three directions.

The first, is to achieve a policy of innovation to influence the behavior of entities at local, regional or national and European level.

The second - innovation is the integration of sectoral policies.

And the third, involves interaction with other innovation policy, namely the introduction of innovation through policies governing the internal market, employment policy, environmental policy and competition policy as well.

The objective of innovation policies is to systematically take into account the innovative aspects of the legislative and politic initiatives.

The main challenges in Romania to increase capacity for innovation are: a) poor integration of research-innovationeducation elements in the knowledge triangle; high costs for patenting;b) reduced mobility of researchers; c) transdisciplinary and interdisciplinary research failure, focus on innovation needs; d) lack of organization and governance research models. Fiscality represents an important determined in innovative behavior. Adding value to patented intellectual property can be achieved by diversification of measures for the development of an attractive jurisdiction

${ }^{3}$ European Commission Enterprise and Industry, European Innovation Scoreboard 2009
The purpose of the fiscality is therefore to determine the entities to consider the review of innovative technological activities.

Increasing research and development activities especially in the private sector is possible by providing fiscal incentives to entities witch unfold research and development activities.

In Romania's case we consider that is necessary to introduce in the current legislation the possibility of an additional deduction in calculating the profit tax at a $20 \%$ rate of eligible costs for research and development activities. We also consider necessary the possibility of applying the accelerated depreciation method also in the case of equipments used in research and development activities.

The diversification of fiscal measures must be made also regarding the intellectual property and to achieve this we assume the decrease of progressive profit tax for intellectual property.

\section{CONCLUSIONS}

Because the development of forming agreements inspires action, for the development of technological innovation in Romania we recommend:

- increasing the protection of intellectual property by adopting and implementing new lows;

- improving co-operation between educational institutions and economic entities;

- reestablishing the balance between the direct support through grants, co-investments or procurement and the indirect support through tax credits;

- rationalizing and simplifying support programs for research and development.

Climate changes and population aging are major social challenges which require the orientation of innovation politic towards the adoption of rules regarding state aids for research and development, innovation in the service area, stimulating the establishment of innovative clusters and granting patents at European level.

All this actions would contribute to the simplification and dissemination of technological innovation and to the improvement of their transfer process form laboratories to the open market.

We consider that developing the idea market does not depend so much on lowering taxes but on increasing the quality of life.

\section{ACKNOWLEDGEMENT}

This work was supported by the project "Post-Doctoral Studies in Economics: training program for elite researchers SPODE" co-funded from the European Social Fund through the Development of Human Resources Operational Programme 2007-2013, contract no. POSDRU/89/1.5/S/61755.

\section{REFERENCES}

Hayek F.A. Drumul către servitute, Ed. Humanitas, Bucuşti, 2006, ISBN 973-50-1122-0

Mill J.S. Principles of Political Economy with some of their Applications to Social Philosophy, Ed. William J. Ashley, London, 1909, 7th edition, ISBN 978-1143594175

Prebisch R. Towards a Dynamic Development for Latin America, United Nations, New York, 1963

Schumpeter J.A. From Capitalism, Socialism and Democracy , Ed. Harper, New York, 1975, ISBN 0-415-10762-8

Schumpeter J.A. Poate supravției capitalismul? Distrugerea creatoare și viitorul economiei globale, Ed Publică, București, 2011, ISBN 978-973-1931-65-4

Tidd J., Bessant J.R., Pavitt K. Managing Innovation: integrating technological, market and organizational change, John Wiley \& Sons Publisher, 2001, ISBN 9780471496151

***European Commission Enterprise and Industry, European Innovation Scoreboard 2009 